\title{
APLIKASI EXCEL FOR ACCOUNTING DALAM MENYUSUN LAPORAN KEUANGAN PADA PEMERINTAHAN DESA
}

\author{
Thobias. E. D, Tomasowa ${ }^{1 *}$, Donny. T. S,. Junias ${ }^{2}$, R. S. Budi Suharto ${ }^{3}$ \\ $1^{*}, 2,3$ Politeknik Negeri Kupang \\ *E-mail: alfredrantelobo@yahoo.co.id
}

\begin{abstract}
Abstrak
Tujuan penelitian ini untuk mengaplikasikan Excel For Accounting (EFA) dalam penyusunan laporan keuangan pada pemerintahan desa dimana Program EFA ini relatif mudah dan dapat dijalankan oleh orang yang tidak paham akuntansi sekalipun. Pendekatan penelitian ini menggunakan penelitian terapan dan bersifat kualitatif. Penelitian dilakukan pada pemerintahan Desa Mata Air Kecamatan Kupang Tengah Kabupaten Kupang Nusa Tenggara Timur.

Obyek penelitian adalah pencatatan dan laporan keuangan pada pemerintahan desa. Data penelitian yang digunakan adalah data primer dengan mengambil langsung pada lokasi penelitian dan data sekunder berupa artikel/kajian teoritis maupun empiris. Teknik analisa data menggunakan pengamatan secara langsung pada Pemerintahan Desa Mata Air dengan cara mengamati, mengidentifikasi, merancang dan terakhir menerapkan aplikasi EFA.

Hasil penelitian menunjukan bahwa pemerrintahan Desa Mata Air hanya membuat laporan realisasi pelaksanaan APBDesa dan belum membuat Laporan Kekayaan milik desa, Pencatatan masih dilakukan secara manual walaupun sudah memiliki komputer/laptop dan masalah sumber daya manusia berkaitan dengan pemahaman tentang pembukuan.
\end{abstract}

Kata Kunci : Laporan Keuangan Pemerintah Desa, Excel For Accounting

\section{PENDAHULUAN}

Penerapan good corporate governance pada sektor publik sudah merupakan suatu keharusan terutama dengan semakin meningkatnya tuntutan masyarakat atas penyelenggaraan tata kelola pemerintahan yang baik, adil, transparan, dan bertanggungjawab. Segenap jajaran penyelenggara negara, baik dalam tataran eksekutif, legislatif, dan yudikatif harus memiliki komitmen bersama untuk menegakkan good government governance dan clean government.

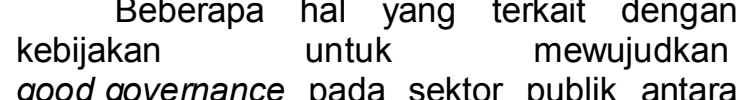
lain meliputi penetapan standar etika dan perilaku aparatur pemerintah, penetapan struktur organisasi dan proses pengorganisasian yang secara jelas mengatur tentang peran dan tanggung jawab serta akuntabilitas organisasi kepada publik, pengaturan sistem pengendalian organisasi yang memadai, dan pelaporan eksternal yang disusun berdasarkan sistem akuntansi yang sesuai dengan standar akuntansi pemerintahan dan Peraturan Pemerintah.
Selanjutnya, berkaitan

dengan akuntabilitas publik, salah satuu perubahan yang signifikan adalah perubahan di bidang akuntansi pemerintahan karena melalui proses akuntansi dihasilkan informasi keuangan yang tersedia bagi berbagai pihak. Perubahan dibidang akuntansi pemerintahan yang paling penting adalah adanya standar akuntansi pemerintah yang dapat dijadikan sebagai sebuah kerangka konseptual dan standar dalam penyelenggaraan akuntansi pemerintahan.

Sebagai bentuk keseriusan pemerintah membenahi akuntansi pemerintahan di Indonesia seperangkat peraturan perundangundangan yang mendukung telah dicanangkan. Diantaranya UU Nomor 17 Tahun 2003 tentang Keuangan Negara, UU No.1 Tahun 2004 tentang Perbendaharaan Negara, yang ditindaklanjuti dengan PP No. 24 Tahun 2005 dan kemudian diganti dengan PP No. 71 Tahun 2010 tentang Standar Akuntansi Pemerintah (SAP). Dengan diterbitkannya PP tersebut, Indonesia memasuki era baru transparansi dan akuntabilitas di bidang keuangan negara. PP ini mengharuskan pemerintah baik pusat maupun daerah menyusun laporan keuangan berupa neraca, 
Thobias. E. D, Tomasowa ${ }^{1 *}$, Donny. T. S,. Junias ${ }^{2}$, R. S. Budi Suharto ${ }^{3}$

laporan realisasi anggaran, laporan arus kas, laporan operasional, laporan perubahan saldo anggaran lebih, laporan perubahan ekuitas dan catatan atas laporan keuangan.Demikian pula dengan pemerintahan desa, sehubungan dengan berlakunya Undang-undang Nomor 6 Tahun 2014 tentang Desa membuat pemerintah Desa akan memperoleh dana yang cukup besar untuk dikelolanya. Di lain pihak tentunya dana yang besar tersebut harus dapat dikelola dan dipertanggungjawabkan dengan baik.

Pengelolaan keuangan Desa tidak hanya menyangkut perlunya peraturan pendukungnya dan sarana-prasarana, namun yang paling penting adalah dimilikinya SDM yang memiliki kompetensi dan komitmen yang dapat diandalkan. Harus disadari bahwa aparat Desa yang ada saat ini sebagian besar memiliki tingkat pendidikan yang relatif rendah. Untuk mempermudah pengelolaan akuntansi dari keuangan Desa sehingga nantinya dapat dipertanggungjawabkan secara benar maka diperlukan pedoman untuk memberikan pemahaman terhadap pengelolaan keuangan Desa dengan cara yang mudah sehingga tidak akan membuat ketakutan bagi siapapun untuk dapat mempertanggungjawabkan pengelolaan keuangan Desa dengan baik.

Adanya perubahan SAP dari berbasis kas menuju akrual menjadi akrual penuh, ditambah lagi sulitnya mendapatkan Iulusan akuntansi yang paham dengan sistem akuntansi pemerintahan yang baru membuat pemerintah desa harus "memutar otak" agar laporan keuangan dapat dihasilkan. Keterbatasan SDM ini juga dipersulit dengan sistem akuntansi manual yang dilaksanakan oleh pemerintahan desa. Hal ini menyebabkan hanya orang-orang yang sangat paham akuntansi yang dapat melakukan.

Untuk mengatasi permasalahan tersebut diatas salah satu solusi yang bisa diambil adalah pengaplikasian program komputer akuntansi khususnya Excel For Accounting (EFA) yang relatif sederhana. EFA hanya diperuntukkan dalam penyusunan laporan keuangan saja dan tidak terintegrasi dengan sistem lainnya. Dengan menginputkan bukti transaksi kita dapat langsung menghasilkan laporan keuangan karena beberapa proses akuntansi manual seperti posting kebuku besar telah dilakukan secara otomatis oleh komputer. Program EFA yang relatif mudah ini dapat dijalankan oleh orang yang tidak paham akuntansi sekalipun. Oleh karena itu, dalam penelitian ini dikembangkan aplikasi pembukuan untuk pemerintahan desa dengan aplikasi Excel For Accounting yang praktis dan mudah dalam menyusun laporan keuangan. Tujuan penelitian merupakan sasaran yang mengacu pada rumusan masalah penelitian, maka tujuan penelitian ini adalah mengaplikasikan Excel For Accounting dalam penyusunan laporan keuangan pada pemerintahan desa.

\section{METODE PENELITIAN}

Jenis penelitian yang dilakukan adalah penelitian terapan dan bersifat kualitatif. Penelitian dilakukan pada pemerintahan Desa Mata Air Kecamatan Kupang Tengah Kabupaten Kupang. Data diambil untuk periode Agustus dan September 2016. Obyek penelitian ini adalah pencatatan dan Laporan Keuangan pada pemerintahan Desa Mata Air Kecamatan Kupang Tengah Kabupaten Kupang. Laporan keuangan terdiri dari Laporan Pertanggungjawaban Realisasi APBDesa dan Laporan Kekayaan Milik Daerah. Teknik pengumpulan data dilakukan dengan cara penelitian lapangan yang diperoleh dengan melakukan penelitian langsung melalui wawancara, observasi dan pengumpulan data berupa dokumen pencatatan dan laporan keuangan, dan studi pustaka melalui literatur-literatur, buletin, majalah, jurnal, undang-undang, peraturan pemerintah dan sumber lainnya.

Adapun langkah-langkah pada analisis penelitian adalah dengan melakukan pengamatan dengan langkah-langkah melihat kondisi pencatatan keuangannya yang telah dilakukan selama ini baik sebelum, saat, dan setelah terjadinya proses ekonomi, mengidentifikasi proses pencatatan dan pelaporan yang telah dilakukan, merancang aplikasi sesuai dengan proses pencatatan yang telah dilakukan permerintahan Desa, antara lain:

1. Merancang kode akun.

2. Merancang Formulir yang digunakan dalam Pengelolaan Keuangan Desa.

3. Menghubungkan antara formulir-formulir yang digunakan untuk input data dengan formulir-formulir yang merupakan Output data. Untuk menghubungkan antara formulir input dan formulir output digunakan berbagai macam fungsi-fungsi dalam Microsoft Ecell antara lain Fungsi aritmatika, fungsi-fungsi dasar, fungsi logika, dan fasilitas lainnya yang ada dalam aplikasi Microsoft Ecell.

\section{HASIL DAN PEMBAHASAN}

Pencatatan keuangan yang digunakan oleh bendahara dalam melakukan penatausahaan penerimaan dan pengeluaran antara lain, buku kas umum, buku kas pembantu pajak dan 
buku bank. Buku kas umum digunakan untuk mencatat seluruh bukti transaksi keuangan desa. Buku kas pembantu pajak digunakan untuk mencatat bukti transaksi terkait dengan pemungutan maupun penyetoran pajak oleh bendahara desa. Buku bank digunakan untuk mencatat bukti transaksi terkait dengan penerimaan maupun pengeluaran melalui bank. Sedangkan dalam penyusunan laporan keuangan desa, diambil dari seluruh proses pencatatan sebelumnya.

Dalam proses Identifikasi pencatatan yang dilakukan oleh Pemerintahan Desa Mata Air Kecamatan Kupang Tengah Kabupaten Kupang ditemukan beberapa kelemahan antara lain:

- Pencatatan/pembukuan masih dilakukan secara manual, walaupun pemerintahan Desa telah memiliki komputer atau laptop tetapi pengerjaannya masih manual. Pekerjaan secara manual ini berpotensi menimbulkan kesalahan-kesalahan dalam pencatatan karena dilakukan pencatatan berulang-ulang kali.

- Bendahara keliru dalam memahami saldo awal antara Buku Kas Umum dan Buku Bank dimana saldo keduanya dianggap sama, seharusnya saldo awal pada Buku Kas Umum menunjukan jumlah uang tunai yang dipegang oleh Bendahara Desa pada awal periode, sedangkan saldo awal Buku Bank menunjukan jumlah uang yang ada direkening bank pada awal periode.

- Laporan Kekayaan Milik Desa belum dibuat sehingga sulit untuk mengetahui berapa sebenarnya aset, kewajiban dan kekayaan bersih Desa pada saat ini.

- Terdapat beberapa transaksi yang tidak memiliki No. bukti transaksi seperti transaksi pemungutan pajak dan penyetoran pajak, padahal seluruh transaksi harus dicatat berdasarkan bukti transaksi.

- Pemerintahan Desa sudah mempunyai daftar akun anggaran tetapi belum mempunyai daftar akun keuangan yang berguna untuk mengklasifikasikan pos atau rekening transaksi.

Pada proses perancangan aplikasi Excell For Accounting didasarkan pada proses pencatatan yang selama ini dilakukan oleh Pemerintahan Desa Mata Air Kecamatan Kupang Tengah Kabupaten Kupang dan identifikasi pada kelemahan-kelemahan yang ditemukan. Ada beberapa langkah yang dilakukan untuk menyusun laporan keuangan dengan menggunakan EFA yaitu :
1. Merancang daftar kode dan nama akun.

Kode akun adalah suatu penamaan/penomoran yang dipergunakan untuk mengklasifikasikan pos atau rekening transaksi. Setiap jenis pos dalam satu sistem akuntansi harus memiliki kode atau nomor yang dapat dibedakan sesuai dengan kelompoknya.

Kode akun yang akan digunakan dalam pencatatan keuangan pemerintahan desa sebaiknya ditetapkan seragam, sehingga laporan keuangan Desa bisa saling diperbandingkan. Bahkan seandainya diperlukan, akan memudahkan dalam melakukan kompilasi laporan keuangan seluruh Desa yang ada pada suatu Kabupaten/Desa.

Rancangan Bagan Akun pada Pemerintahan Desa Mata Air Kecamatan Kupang Tengah Kabupaten Kupang dapat dilihat pada gambar dibawah ini:

\section{Gambar 1. Kode Rekening Pendapatan}

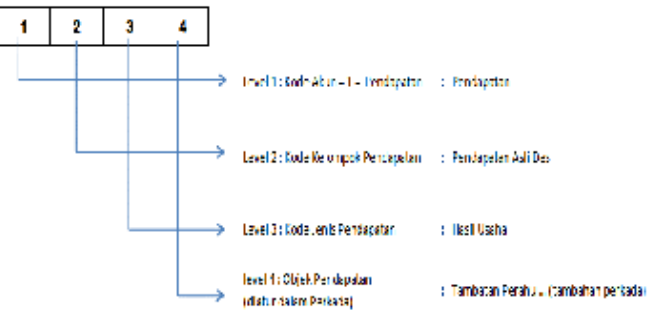

Gambar 2. Kode Rekening Belanja Desa

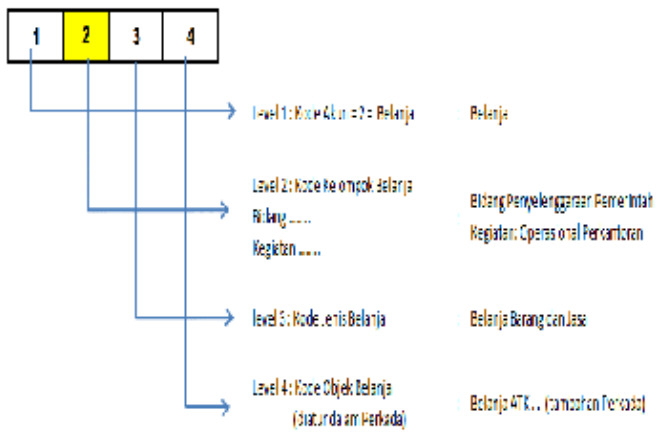

Gambar 3. Kode Rekening Pembiayaan Desa

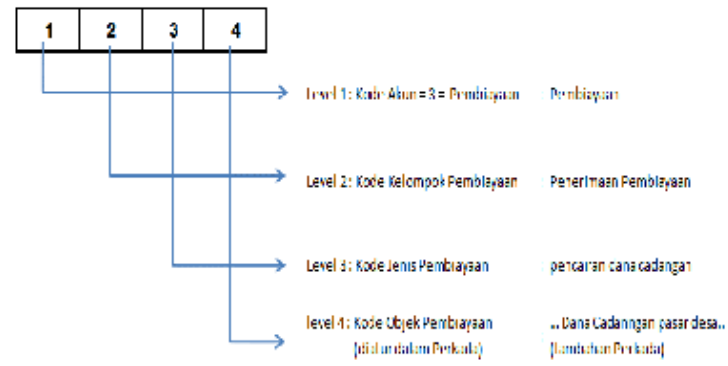


2. Merancang Formulir yang digunakan dalam Pengelolaan Keuangan Desa.

Bendahara Desa wajib melakukan pencatatan terhadap seluruh transaksi yang ada berupa penerimaan dan pengeluaran. Bendahara Desa melakukan pencatatan secara sistematis dan kronologis atas transaksi-transaksi keuangan yang terjadi. Penatausahaan keuangan desa yang dilakukan oleh Bendahara Desa dilakukan dengan cara sederhana, yaitu berupa PEMBUKUAN belum menggunakan jurnal akuntansi.

Berdasarkan keadaan diatas maka dirancangan formulir-formulir yang dapat digunakan untuk menyusun laporan keuangan dengan menggunakan jurnal akuntansi dengan Triple Entry System. Formulir-formulir tersebut terdiri dari.

- Formulir Menu

Pada formulir ini, dimasukan data instansi dan data akuntansi antara lain: mengenai nama instansi, alamat, periode laporan keuangan dan tahun.

Gambar 4. Formulir Menu Utama

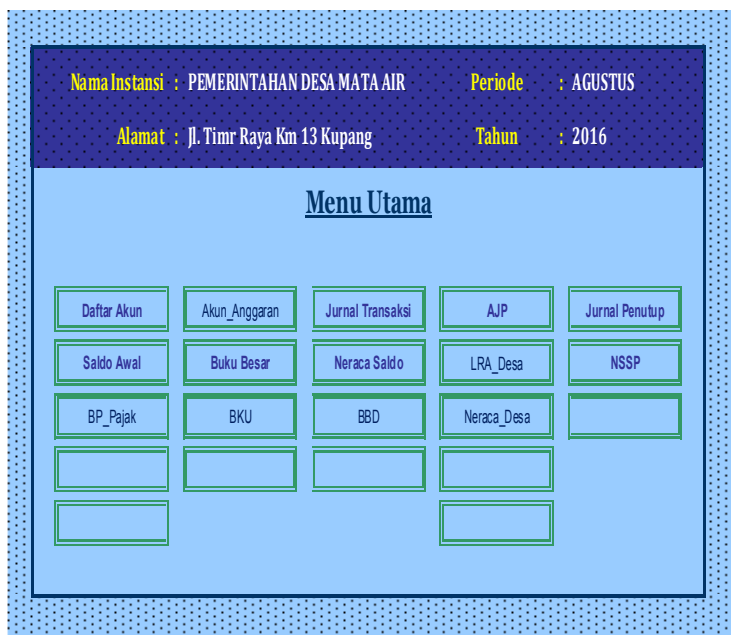

Formulir Saldo Awal

Pada formulir ini, dimasukan saldo awal aset, kewajiban dan kekayaan bersih. Harus ada keseimbangan antara sisi debit dan kredit. Saldo awal aset ada disisi debit, sedangkan sisi kredit adalah saldo awal kewajiban dan kekayaan bersih. Jika tidak seimbang harus dicari letak kesalahannya dan dilakukan koreksi sehingga terjadi keseimbangan antara sisi debit dan kredit.
Gambar 5. Formulir Saldo Awal

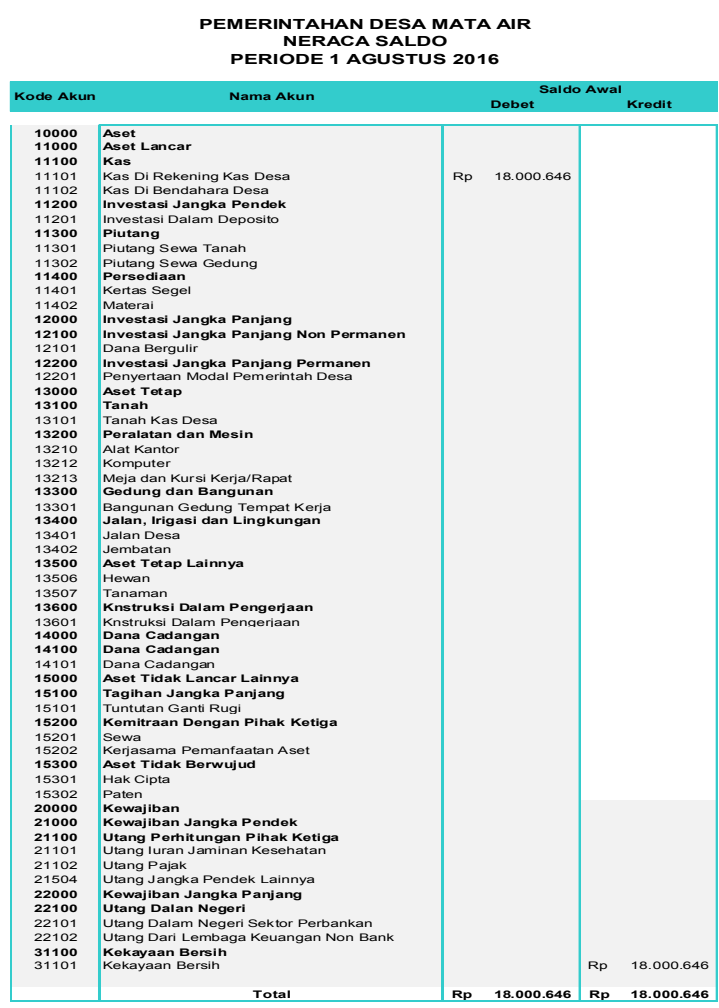

- Formulir akun

Formulir ini berisi kode dan nama akun yang akan digunakan. Daftar perkiraan merupakan tabel yang berisi nomor akun dan nama akun. Daftar perkiraan ini sangat penting dan merupakan formulir kunci dalam EFA.

\section{Gambar 6. Formulir Akun \\ PEMERıv i mumiv uLUm MATA AIR DAFTAR AKUN}

\begin{tabular}{|c|l|}
\hline Kode Akun & \multicolumn{1}{|c}{ Nama Akun } \\
\hline 10000 & Aset \\
11000 & Aset Lancar \\
11100 & Kas \\
11101 & Kas Di Rekening Kas Desa \\
11102 & Kas Di Bendahara Desa \\
11103 & Kas Lainnya \\
11104 & Setara Kas \\
11200 & Investasi Jangka Pendek \\
11201 & Investasi Dalam Deposito \\
11202 & Investasi Dalam Saham \\
11203 & Investasi Jangka Pendek Lainnya \\
11300 & Piutang \\
11301 & Piutang Sewa Tanah \\
11302 & Piutang Sewa Gedung \\
11303 & Piutang PAD Desa Lainnya \\
11304 & Piutang Transfer Dana Desa \\
11305 & Piutang Transfer Alokasi Dana Desa \\
11306 & Piutang Bagi Hasil PAD Kab/Kota \\
11307 & Pitang Pendapatan Lainnya \\
11400 & Persediaan \\
\hline
\end{tabular}


- Formulir Jurnal Transaksi

Formulir ini digunakan untuk mencatat seluruh transaksi, baik itu transaksi penerimaan maupun pengeluaran secara kronologis. Pada formulir ini terdapat kolom Tanggal, kolom No. Bukti, kolom Kode Anggaran, kolom Keterangan, kolom Debit (kode akun, nama akun, jumlah) dan kolom Krebit (kode akun, nama akun, jumlah).

Untuk menghindari terjadinya kesalahan dalam pengisian, maka pada kiri atas tabel ada Cek Saldo yang berfungsi untuk memberikan tanda apabila terjadi kesalahan pencatatan terutama salah mencatat jumlah angka. Jika diisi dengan benar maka Cek Saldo akan tampak pernyataan "Saldo Seimbang", jika tidak akan tampak pernyataan "Saldo Tidak Seimbang" dan berwarna merah. Sehingga kesalahan yang terjadi segera diketahui dan dapat segera dikoreksi.

\section{Gambar 7. Formulir Jurnal Transaksi}

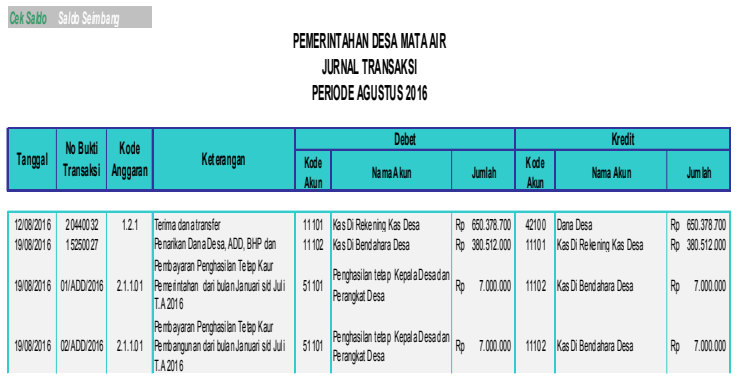

- Formulir Buku Besar

Formulir ini merupakan formulir output yang secara otomatis termuktahirkan ketika formulir jurnal transaksi telah diinput data.

\begin{tabular}{|c|c|c|c|c|c|}
\hline \multicolumn{6}{|c|}{$\begin{array}{c}\text { PEMERINTAHAN DESA MATA AIR } \\
\text { BUKU BESAR } \\
\text { PERIODE AGUSTUS 2016 }\end{array}$} \\
\hline Kode Akun & 11101 & & & Saldo Aval & Rp 18.000 .646 \\
\hline NamaAkum & \multicolumn{3}{|c|}{ Kas D R Rekening Kas Dea } & Saldo Akhir & RP 53.055.746 \\
\hline Tanggal & $\begin{array}{l}\text { No Bulki } \\
\text { Transalks }\end{array}$ & Unian Tranaksi & Debet & Kredit & Saldo \\
\hline 010822016 & & Saldo Aval & $\operatorname{Rp} 18.000 .664$ & Rp & $\operatorname{Rp} 18.000 .646$ \\
\hline 12082016 & 2044032 & Terima dena trasiffer & $\operatorname{Rp} 650.0378 .700$ & & $\operatorname{Rp} 668.379 .346$ \\
\hline 190822016 & 15250027 & Penarikan Dana Dese, ADD, BHP dan SLIPA & & Rp 380.512:000 & $\operatorname{Rp} 287.867 .346$ \\
\hline 22082016 & 15250139 & Penarkikan Dana ADD & & Rp 51.640 .000 & $\operatorname{Rp} 236.227 .346$ \\
\hline 22082016 & 15250141 & 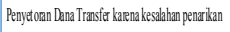 & Rp 300.000 & & Rp 236.527 .346 \\
\hline 29082016 & 15250066 & Penarikan Dana Desadan ADD & & Rp 84.133 .800 & $\operatorname{Rp} 1523.393 .346$ \\
\hline 30082016 & 15250038 & Penarkan Dana DesaAAD dan SLLPA & $\mathrm{Rp}$ & Rp 993379.800 & $\operatorname{Rp} 533.055 .746$ \\
\hline & Total & & $\operatorname{Rp} 668.6979346$ & $\operatorname{Rp} 615.623600$ & \\
\hline
\end{tabular}

- Formulir Buku Kas Umum

Formulir ini juga merupakan formulir output yang secara otomatis termuktahirkan ketika formulir jurnal transaksi telah diinput data. Data pada buku ini akan sama dengan data pada Buku Besar kode akun (11102) Kas Di Bendahara Desa.

\section{Gambar 9. Formulir Buku Kas Umum BUKU KAS UMUM PEMERINTAHAN DESA MATA AIR KECAMATAN KUPANG TENGAH} Kode Akun $\quad 11102$

\begin{tabular}{|c|c|c|c|c|c|c|c|c|}
\hline Na & Tgl. & $\begin{array}{c}\text { KODE } \\
\text { REKENNG }\end{array}$ & URAAAN & $\begin{array}{c}\text { PENERIMAAN } \\
(\text { Rp. })\end{array}$ & $\begin{array}{c}\text { PENGELUARAN } \\
(\mathrm{RP} .)\end{array}$ & NOBUKTI & $\begin{array}{l}\text { JUMLAH } \\
\text { PEVEELAARAN } \\
\text { KOMULATIF }\end{array}$ & SALDO \\
\hline & 2 & 3 & 4 & 5 & 6 & 7 & 8 & 9 \\
\hline & $0108 / 2016$ & & Saldo Awal & & & 0 & & \\
\hline & & & & $R_{p}$ & $R_{p}$ & & $\mathrm{Rp}_{\mathrm{p}}$ & $\mathrm{Rp}$ \\
\hline & 1908/2016 & 0 & $\begin{array}{l}\text { Penarikan Dana Desa, } \\
\text { ADD, BHP dan SILPA }\end{array}$ & Rp380.512.000 & Ro & 15250027 & Rp & Rp 380.512.000 \\
\hline & 1908/2016 & 2.1.1.01 & \begin{tabular}{|c|} 
Pembayaran \\
Penghasilar Tetap \\
Kaur Pemerintahan \\
dari bulan Januari ild \\
Juli T.A2016
\end{tabular} & $R p$ & $|\operatorname{Rp} \quad 7.000 .000|$ & 01/ADD/2016 & Rp $\quad 7.000 .000$ & Rp 373.512.000 \\
\hline & 1908/2016 & 2.1.1.01 & \begin{tabular}{|c|} 
Pembayaran \\
Penghasilan Tetap \\
Kaur Pembangunan \\
dari bulan Januari is \\
Juli TA2016 \\
\end{tabular} & $R p$ & $\left|\begin{array}{|ll}\operatorname{Rp} & 7.000 .000\end{array}\right|$ & 02/ADD/2016 & Rp $\quad 14.000 .000$ & Rp 366.512.000 \\
\hline
\end{tabular}

- Formulir Buku Kas Pembantu Pajak Formulir ini juga merupakan formulir output yang secara otomatis termuktahirkan ketika formulir jurnal transaksi telah diinput data. Data pada buku ini akan sama dengan data pada Buku Besar kode akun (11102) Utang Pajak.

$$
\begin{gathered}
\text { Gambar 10. Formulir } \\
\text { Buku Kas Pembantu Pajak } \\
\text { BUKU KAS PEMBANTU PAJAK } \\
\text { PEMERINTAHAN DESA MATA AIR KECAMATAN KUPANG TENGAH } \\
\text { TAHUN ANGGARAN } 2016
\end{gathered}
$$

\begin{tabular}{|c|c|c|c|c|c|}
\hline \multicolumn{2}{|r|}{ Kode Akun } & \multicolumn{2}{|l|}{21102} & \multirow[b]{2}{*}{\begin{tabular}{|c} 
PENYETORAN \\
(Rp.)
\end{tabular}} & \multirow[b]{2}{*}{$\begin{array}{l}\text { SALDD } \\
\text { (Rp.) } \\
\end{array}$} \\
\hline No. & TANGGAL & URAIAN & $\begin{array}{l}\text { PEMOTONGAN } \\
(\text { Rp.) }\end{array}$ & & \\
\hline 1 & 2 & 3 & 4 & & 5 \\
\hline & 01/08/2016 & Saldo Awal & & & $\mathrm{Rp}$ \\
\hline & 19/08/2016 & Pungut PPN Pajak Pengadaan papan profil & $\begin{array}{l}\mathrm{Rp} \\
734.090\end{array}$ & Rp & $\begin{array}{l}\mathrm{Rp} \\
734.090\end{array}$ \\
\hline & 19/08/2016 & $\begin{array}{l}\text { Pungut PPh } 22 \text { Pajak Pengadaan papan } \\
\text { profil }\end{array}$ & \begin{tabular}{|l} 
Rp \\
220.227
\end{tabular} & Rp & \begin{tabular}{|l}
$R p$ \\
Rp4.317
\end{tabular} \\
\hline & 19/08/2016 & Pungut PPh 21 Pajak honor Pendataan & $\begin{array}{l}\mathrm{Rp} \\
390.000\end{array}$ & Rp & $\begin{array}{l}\mathrm{Rp} \\
1.344 .317\end{array}$ \\
\hline
\end{tabular}

- Formulir Buku Bank Desa

Formulir ini juga merupakan formulir output yang secara otomatis termuktahirkan ketika formulir jurnal transaksi telah diinput data. Data pada buku ini akan sama dengan data pada Buku Besar kode akun (11101) Kas Di Rekening Kas Desa. 
Thobias. E. D, Tomasowa ${ }^{1}$, Donny. T. S,. Junias ${ }^{2}$, R. S. Budi Suharto ${ }^{3}$

Gambar 11. Formulir Buku Bank Desa BUKUBANKDESA
PENERNTAHAN DESA MATA ARR KECAMATAN KUPANG TENGAH TAHUNANGGRAN 2016

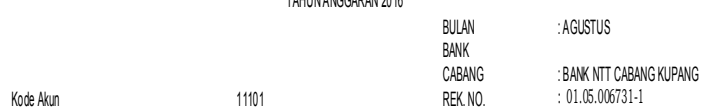

\begin{tabular}{|c|c|c|c|c|c|c|c|c|c|}
\hline \multirow{2}{*}{\multicolumn{2}{|c|}{$\begin{array}{l}\text { T. TANGGGL } \\
\text { TRASAKS }\end{array}$}} & \multirow[b]{2}{*}{ URAANTRANSAKSI } & \multirow[b]{2}{*}{\begin{tabular}{|c|c} 
BUKT \\
TRANAKSS
\end{tabular}} & \multicolumn{2}{|c|}{ PEMASUKAN } & \multicolumn{3}{|c|}{ PENGELLARAN } & \multirow[b]{2}{*}{ SALDO } \\
\hline N & & & & $\begin{array}{c}\text { SETORAN } \\
\text { (RP.) }\end{array}$ & $\begin{array}{c}\text { BUWGA } \\
\text { BANK } \\
\text { RRP.) } \\
\end{array}$ & $\begin{array}{c}\text { PENARIKAN } \\
\text { (Rpo.) }\end{array}$ & $\begin{array}{l}\text { PAAKK } \\
\text { RP.) }\end{array}$ & $\begin{array}{c}\text { BIAYA } \\
\text { ADMNISTRAS } \\
\text { (PQ.). }\end{array}$ & \\
\hline 1 & 2 & 3 & 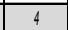 & 5 & 6 & 7 & 8 & 9 & 10 \\
\hline & 010822016 & Saldo Awal & & & & & & & \begin{tabular}{|l|l}
$R p$ \\
180000.646
\end{tabular} \\
\hline & 120822016 & Terima dana a transfler & 20440032 & $\begin{array}{l}\operatorname{Rp} \\
650.378 .700\end{array}$ & & Rp & & & Rro668379.34 \\
\hline & 1908:2016 & $\begin{array}{l}\text { Peraikan Dana Desa, ADD, BHP dan } \\
\text { SlLPA }\end{array}$ & 15250027 & Rp & & Rp380.512.000 & & & Rp287.867.34 \\
\hline & 2208822016 & Peranikan Dana ADD & 15250139 & $\operatorname{Rp}$ & & $\begin{array}{l}\mathrm{RP} \\
51.640 .000\end{array}$ & & & RR2336.277.34 \\
\hline
\end{tabular}

- Formulir Neraca Saldo

Formulir ini juga merupakan formulir output yang secara otomatis termuktahirkan ketika formulir jurnal transaksi dan jurnal penyesuaian telah diinput data.

Gambar 12. Formulir Neraca Saldo

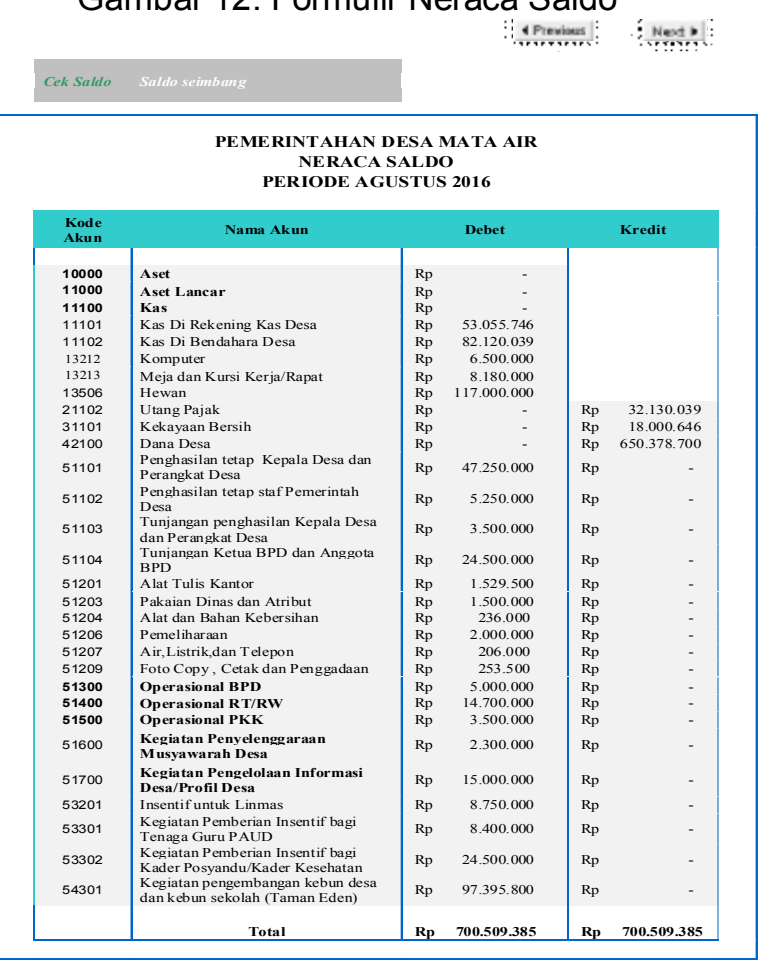

- Formulir Ayat Jurnal Penyesuaian (AJP) Formulir ini digunakan untuk mencatat transaksi yang sudah terjadi tetapi belum dicatat atau koreksi atas kesalahan.
Gambar 13. Formulir Ayat Jurnal Penyesuaian (AJP)

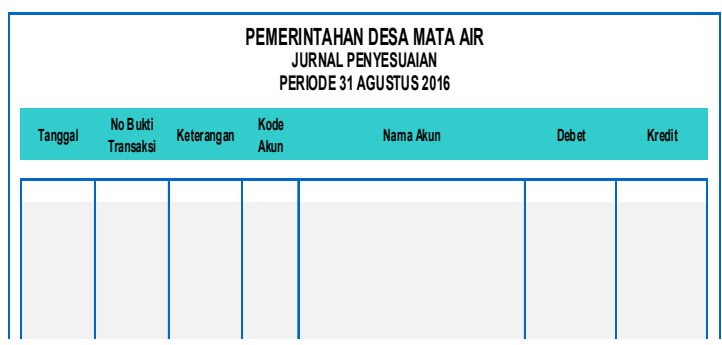

- Formuir Laporan Pertanggungjawaban Pelaksanaan Realisasi APBDesa

Formulir ini juga merupakan formulir output. Hanya kolom realisasi bulan ini, s/d bulan ini dan lebih/kurang yang termuktahirkan secara otomatis ketika formulir jurnal transaksi telah diinput data, sedangkan kolom lainnya harus diisi secara manual pada awal proses.

Gambar 14. Formulir Laporan Pertanggungjawaban Pelaksanaan Realisasi APBDesa

$$
\begin{array}{|l}
\text { Lampiran I Peraturan Desa } \\
\text { Nomor :.......... } \\
\text { Tentann :Laporan Pertanggungajawaban } \\
\text { Realisasi Pelaksanaan APBDes } \\
\text { Teatun Anggaranan } 2016 \\
\hline
\end{array}
$$

\begin{tabular}{|c|c|c|c|c|c|c|c|}
\hline \multirow{2}{*}{ KOOE } & \multirow{2}{*}{ URAIAN } & \multirow{2}{*}{ ANGGARAN (Rp.) } & \multicolumn{3}{|c|}{ REALSASI (Rp.) } & \multirow{2}{*}{$\begin{array}{c}\text { LEBH KURANG } \\
\text { (Rp.) }\end{array}$} & \multirow{2}{*}{ KET. } \\
\hline & & & $\begin{array}{l}\text { SD BULAN } \\
\text { LALU }\end{array}$ & BULANIN| & SIDBULAN IN & & \\
\hline 1 & 2 & 3 & 4 & 5 & 6 & 7 & 8 \\
\hline 1 & PENDAPATAN & Rp 1.093.964.500 & $\operatorname{Rp} 656.848 .100$ & $\operatorname{Rp} 650.378 .700$ & $\operatorname{Rp} 1.307 .226 .800$ & Rp 213.262.300 & \\
\hline 1.1 & Pendapatan AsliDesa & $\operatorname{Rp} \quad 10.000 .000$ & $\operatorname{Rp} 6.469 .400$ & $\mathrm{Rp}$ & $\begin{array}{ll}\operatorname{Rp} & 6.469 .400 \\
\end{array}$ & \begin{tabular}{ll|}
$\operatorname{Rp}$ & 3.530 .600 \\
\end{tabular} & \\
\hline 1.1 .1 & Hasill Usaha Desa & & & $\mathrm{Rp}$ & \begin{tabular}{|ll}
$\mathrm{Rp}$ \\
\end{tabular} & Rp & \\
\hline 1.1 .2 & Hasil aset desa & & & $\mathrm{Rp}$ & $\mathrm{Rp}$ & $\mathrm{Rp}$ & \\
\hline 1.1 .3 & $\begin{array}{l}\text { Sviadaya, partisipasi dan } \\
\text { gotonng pyong }\end{array}$ & & & Rp & Rp & Rp & \\
\hline 1.1 .4 & $\begin{array}{l}\text { Lain-bin pendapatan asil } \\
\text { dessa yang sah }\end{array}$ & Rp $\quad 10.000 .000$ & 6.469 .400 & Rp & Rp $\quad 6.469 .400$ & $\operatorname{Rp} \quad 3.530 .600$ & \\
\hline & & & & & & & \\
\hline 1.2 & Pendapatan transfer & Rp 1.083.964.50 & $\operatorname{Rp} 650.378 .700$ & $\operatorname{Rp} 650.378 .700$ & $\operatorname{Rp} 1.300 .757,400$ & $\operatorname{Rp}(216.792900)$ & \\
\hline 1.2 .1 & Dana desa & $\operatorname{Rp} 637.131 .000$ & $\operatorname{Rp} 382.278 .600$ & $\operatorname{Rp} 650.378 .700$ & $\operatorname{Rp} 1.032 .657 .300$ & $\operatorname{Rp}(395.526 .300)$ & \\
\hline 1.2 .2 & \begin{tabular}{|l|} 
Bagi Hasi Pajak Dan \\
Retribusi Daerah
\end{tabular} & Rp $\quad 4.234 .500$ & Rp 2.540 .700 & Rp & Rp $\quad 2.540 .700$ & $\operatorname{Rp} \quad 1.693 .800$ & \\
\hline 1.2 .3 & Alokasi Dana Deasa & $\operatorname{Rp} \quad 442.599 .000$ & Rp 266.559.400 & $\mathrm{Rp}$ & $\begin{array}{|ll|}\text { Rp } \quad 265.559 .400 \\
\end{array}$ & $\operatorname{Rp} \quad 177.089 .000$ & \\
\hline 1.2 .4 & Bantuan Keuangan & & & & & & \\
\hline
\end{tabular}

LAPORAN PERTANGGUNGJANABANREALISASI PELLKSANAANAPBDESa PEMERINTAHAN DESA MATA AIR TAHUN ANGGARAN 2016

- Formulir Laporan Kekayaan Milik Desa Formulir ini juga merupakan formulir output. Kolom tahun sebelumnya diisi secara manual pada awal proses, sedangkan kolom tahun pelaporan akan termuktahirkan secara otomatis ketika formulir jurnal transaksi telah diinput data. 
Gambar 15. Formulir Laporan Kekayaan Milik Desa \begin{tabular}{|l|}
\hline Lampiran II Peraturan Desa \\
Nomor : ......... \\
Tentang : Laporan Kekayaan Milik \\
Sampai Dengan 31 AGUSTUS 2016 \\
\hline
\end{tabular}

\begin{tabular}{|c|c|c|c|}
\hline KODE & URAIAN & $\begin{array}{c}\text { TAHUN N (Tahun } \\
\text { Periode } \\
\text { Pelaporan) }\end{array}$ & $\begin{array}{l}\text { TAHUN N-1 } \\
\text { (Tahun } \\
\text { Sebelumnva) }\end{array}$ \\
\hline $\begin{array}{l}11101 \\
11102 \\
11301 \\
11302 \\
11401 \\
11402\end{array}$ & $\begin{array}{l}\text { I. ASET DESA } \\
\text { A. ASET LANCAR } \\
\text { 1. Kas Desa } \\
\text { a. Uang kas di Bendahara Desa } \\
\text { b. Rekening Kas Desa } \\
\text { 2. Piutang } \\
\text { a. Piutang Sewa Tanah } \\
\text { b. Piutang Sewa Gedung } \\
\text { 3. Persediaan } \\
\text { a. Kertas Segel } \\
\text { b. Materai }\end{array}$ & $\begin{array}{lr}R p & 135.175 .785 \\
R p & 53.055 .746 \\
R p & 82.120 .039 \\
R p & - \\
R p & - \\
R p & - \\
R p & - \\
R p & - \\
R p & -\end{array}$ & $\begin{array}{lr}\text { Rp } & \mathbf{1 8 . 0 0 0 . 6 4 6} \\
& \\
\text { Rp } & 18.000 .646 \\
\text { Rp } & \mathbf{5 . 0 0 0 . 0 0 0} \\
R p & 5.000 .000 \\
& \\
\text { Rp } & \mathbf{8 0 0 . 0 0 0} \\
R p & 600.000 \\
R p & 200.000\end{array}$ \\
\hline $\begin{array}{l}12201 \\
13104 \\
13212 \\
13213 \\
13301 \\
13401 \\
14101 \\
13506\end{array}$ & $\begin{array}{l}\text { JUMLAH ASET LANCAR } \\
\text { B. ASET TETAP } \\
\text { 1. Investasi Permanen } \\
\text { - Penyertaan Modal Pemerintah Desa } \\
\text { 2. Aset Tetap } \\
\text { - Tanah } \\
\text { - Komputer } \\
\text {-'Meja dan Kursi Kerja/Rapat } \\
\text { - Gedung dan bangunan } \\
\text { - - Jalan, Jaringan dan Instalasi } \\
\text { 3. Dana Cadangan } \\
\text { - Dana Cadangan } \\
\text { 4. Aset Tidak Lancar Lainnya } \\
\text { - Hewan }\end{array}$ & $\begin{array}{lr}\text { Rp } & - \\
R p & - \\
R p & 182.562 .800 \\
R p & - \\
R p & 6.500 .000 \\
R p & 8.180 .000 \\
R p & - \\
R p & 167.882 .800 \\
R p & - \\
R p & - \\
R p & 117.000 .000 \\
R p & 117.000 .000\end{array}$ & $\begin{array}{lr}\text { Rp } & 23.800 .646 \\
& \\
R p & - \\
R p & - \\
R p & 364.460 .000 \\
R p & 200.000 .000 \\
R p & - \\
R p & 14.460 .000 \\
R p & 50.000 .000 \\
R p & 100.000 .000 \\
R p & - \\
R p & - \\
R p & - \\
R p & -\end{array}$ \\
\hline 21102 & $\begin{array}{l}\text { JUMLAH ASET TETAP } \\
\text { JUMLAH ASET (A+B) } \\
\text { II. KEWAJIBAN JANGKA PENDEK } \\
\text { - Utang Pajak }\end{array}$ & \begin{tabular}{|ll}
$R p$ & 299.562 .800 \\
$R p$ & 434.738 .585 \\
\end{tabular} & $\begin{array}{l}\operatorname{Rp} 364.460 .000 \\
\operatorname{Rp} 388.260 .646 \\
\end{array}$ \\
\hline & JUMLAH KEWAJIBAN JANGKA PENDEK & 32.130 .039 & $\mathrm{Rp}$ \\
\hline & JUMLAH KEKAYAAN BERSIH (I-II) & $\begin{array}{l}\text { Rp } 402.608 .546 \\
\end{array}$ & Rp 388.260.646 \\
\hline
\end{tabular}

- Formulir Jurnal Penutup

Formulir ini digunakan untuk menutup rekening nominal yaitu rekening pendapatan dan belanja, ditutup ke rekening kekayaan bersih.

Gambar 16. Formulir Jurnal Penutup

\begin{tabular}{|c|c|c|c|c|c|c|c|}
\hline \multicolumn{8}{|c|}{$\begin{array}{l}\text { PEMERINTAHAN DESA MATA AIR } \\
\text { JURNAL PENUTUP } \\
\text { PERIDE } 31 \text { AGUSTUS } 2016\end{array}$} \\
\hline Tanggal & $\begin{array}{l}\text { No Bukti } \\
\text { Transaksi }\end{array}$ & Keterangan & $\begin{array}{l}\text { Kode } \\
\text { Akun }\end{array}$ & Nama Akun & Debet & & Kredit \\
\hline 31/082016 & JP.01 & Penutup & 42100 & Dara Desa & RP 650.378 .700 & & \\
\hline 31/082016 & JP-01 & Penutup & 51101 & $\begin{array}{l}\text { Penghasilan tetap Kepda Desa dan } \\
\text { Perrnokat Desa }\end{array}$ & & $\mathrm{Rp}$ & 47250.000 \\
\hline 31/082016 & JP.01 & Pentup & 51102 & Penahasilan tetap staf Pemerintah Desa & & Ro & 5250.000 \\
\hline 31/082:2016 & JP-01 & Pentup & 51103 & $\begin{array}{l}\text { Tunjangan penghasilan Kepala Desa dan } \\
\text { Perngkat Desa }\end{array}$ & & Rp & 3.500 .000 \\
\hline 31/082016 & JP.01 & Pentup & 51104 & Tunjangan Ketua BPD dan Angoota BPD & & Rp & 24.500 .000 \\
\hline 31/082016 & JP.01 & Pentup & 51201 & Abt Tulis Kantor & & $\mathrm{Rp}$ & 1.529 .500 \\
\hline 31/082016 & JP.01 & Penutup & 51203 & Pakian Dinas dan Arrbut & & $\mathrm{Rp}$ & 1.500 .000 \\
\hline 31/082016 & JP.01 & Pentup & 51204 & Aat dan Bahan Kebersihan & & $\mathrm{Rp}$ & 236.000 \\
\hline 31/082016 & JP.01 & Pentup & 51206 & Pemeliharaan & & $\mathrm{Rp}$ & 2.000 .000 \\
\hline 31/082016 & JP.01 & Pentup & 51207 & Ar, Listrik,dan Telepon & & $R_{p}$ & 206.000 \\
\hline 31/082016 & JP.01 & Pentup & 51209 & Foto Copy, Cetak dan Penggadaan & & $\mathrm{Rp}$ & 253.500 \\
\hline 31/082016 & JP.01 & Pertup & 51300 & Operasional BPD & & $\mathrm{Rp}$ & 5.000 .000 \\
\hline 31/082016 & JP-01 & Pentup & 51400 & Operasional RTRW & & $\mathrm{Rp}$ & 14.700 .000 \\
\hline 31/082016 & JP-01 & Pentup & 51500 & Ooerasional PKK & & Ro & 3.500 .000 \\
\hline 31/082016 & JP-01 & Penutup & 51600 & Kegiatan Penyelenggaraan Musyawarah Desa & & Rp & 2.300 .000 \\
\hline 311082016 & JP-01 & Pentup & 51700 & \begin{tabular}{|l} 
Kegiatan Pengadolazan Irformasi Desaliprofil \\
Desa
\end{tabular} & & Rp & 15.000 .000 \\
\hline 31/082016 & JP-01 & Pentup & 5201 & | Insenfiff untuk Limas & & $\operatorname{Rp}$ & 8.750 .000 \\
\hline 31/08212016 & JP-01 & Pentup & 53301 & $\begin{array}{l}\text { Kegiatan Pemberian Insentit bag Tenaga Guru } \\
\text { PAUD }\end{array}$ & & & 8.400 .000 \\
\hline 31/082016 & JP.01 & Pentup & 53302 & \begin{tabular}{|l|} 
Kegiatan Pemberian Insentit bag Kader \\
Possjandi Kader Keseshadan
\end{tabular} & & Rp & 24.500 .000 \\
\hline 311082016 & JP-01 & Pentup & 54301 & $\begin{array}{l}\text { Kegitan pengembangan kebun desa dan } \\
\text { ketun sekdalah (Taman Eden) }\end{array}$ & & & 97.395 .800 \\
\hline 31/082016 & JP-01 & Pentup & 31101 & 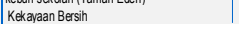 & & $R_{\mathrm{R}}$ & 384.607 .900 \\
\hline
\end{tabular}

- Formulir Neraca Saldo Setelah

Penutupan

Formulir ini juga merupakan formulir

output yang secara otomatis

termuktahirkan ketika formulir jurnal

transaksi dan jurnal penutup telah diinput data.

\section{Gambar 17. Formulir}

Neraca Saldo Setelah Penutupan

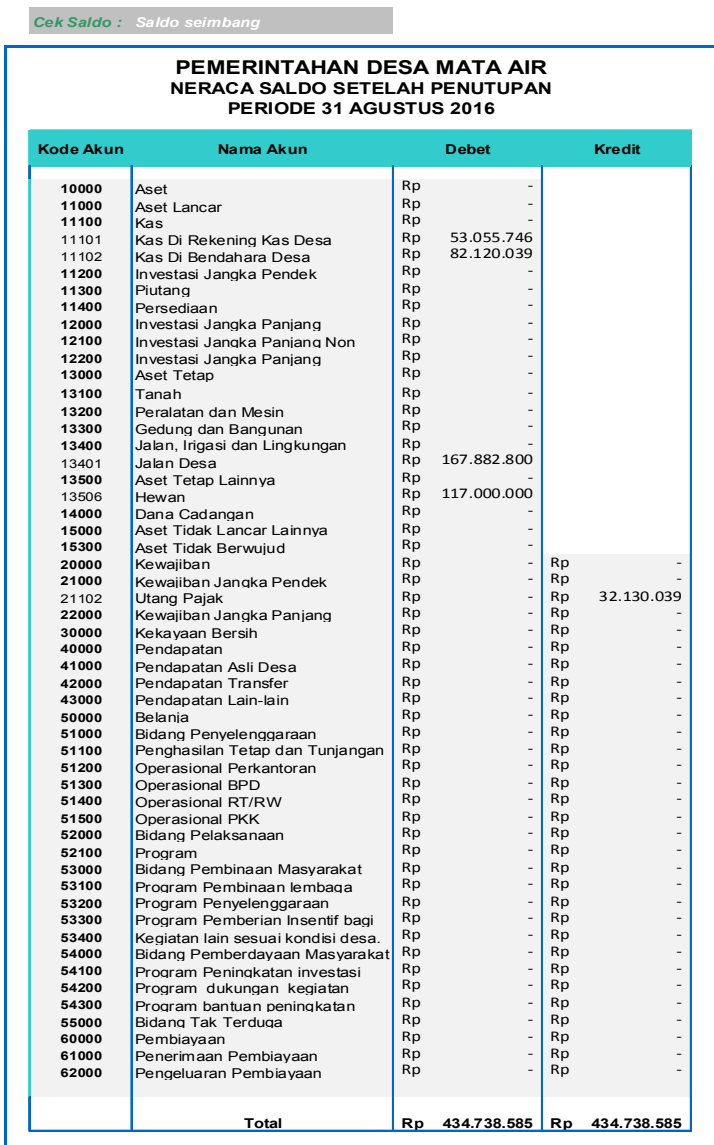

\section{PENUTUP}

Pemerintahan Desa Mata Air Kecamatan Kupang Tengah Kabupaten Kupang masih menggunakan single entry system atau tata buku tunggal dalam melakukan pencatatan terhadap seluruh transaksi, baik berupa penerimaan dan pengeluaran. Bendahara Desa melakukan pencatatan secara sistematis dan kronologis atas transaksi-transaksi keuangan yang terjadi.tetapi belum menerapkan pencatatan dengan doeble entry atau tata buku berpasangan.

Pencatatan masih dilakukan secara manual, walaupun sudah memiliki komputer atau laptop. Pencatatan dilakukan oleh Bendahara dengan menggunakan buku kas umum, buku pembantu pajak dan buku bank. Pemerintahan Desa Mata Air sudah memiliki bagan akun anggaran tetapi belum 
mempunyai bagan akun keuangan yang berguna untuk menyusun lapran kekayaan milik desa. Pemerintahan Desa Mata Air belum membuat laporan kekayaan milik Desa, mereka hanya membuat laporan realisasi anggaran saja,

Aplikasi komputer Excel For Accounting merupakan salah satu media yang dapat digunakan oleh pemerintahan Desa untuk mempermudah, mempercepat dan menghasilkan laporan keuangan yang lebih akurat. Cukup satu kali membuat formatformat maka setelah itu dengan menginput transaksi ke jurnal dengan Triple Entry System secara otomatis proses posting dan laporan keuangan langsung dihasilkan. Kemudahan ini tentu saja akan sangat membantu mengingat keterbatasan sumber daya manusia dan segala keterbatasan lainnya yang ada pada pemerintahan Desa dalam menyusun laporan keuangannya.

Pemerintahan Desa Mata Air harus merubah pola pikirnya menjadi lebih maju dengan menggunakan aplikasi akuntansi yang sudah banyak ada dan mudah untuk didapatkan, seperti EFA, dan juga harus mempunyai Laporan Kekayaan Milik Desa karena salah satu lampiran dari Laporan Pertanggungjawaban Pelaksanaan APB Desa adalah Laporan Kekayaan Milik Desa (Laporan KMD).

\section{DAFTAR PUSTAKA}

Bastian, Indra, (2002). Sistem Akuntansi Sektor Publik 1, Konsep untuk Pemerintahan Daerah, Jakarta : Salemba Empat

Halim, Abdul. Kusufi, Muhammad Syam (2013). Akuntansi Sektor PublikAkuntansi Keuangan Daerah, Jakarta: Salemba Empat

Pandia, Henri. 2005. Teknologi Informasi dan Komunikasi. Bandung: Erlangga. IAIKASP. 2015| Pedoman Asistensi Akuntansi Keuangan Desa

Peraturan Menteri Dalam Negeri No. 13 Tahun 2006, Pedoman Pengelolaan Keuangan Daerah, Departemen Dalam Negeri Republik Indonesia

Peraturan Menteri Dalam Negeri No. 59 Tahun 2007, Pedoman Pengelolaan Keuangan Daerah, Departemen Dalam Negeri Republik Indonesia

Peraturan Pemerintah No. 71 Tahun 2010, Standar Akuntansi Pemerintahan

Undang-Undang Nomor 6 Tahun 2014 tentang Desa 